NBER WORKING PAPER SERIES

\title{
DOES COMPETITION ENCOURAGE CREDIT PROVISION? EVIDENCE FROM AFRICAN TRADE CREDIT RELATIONSHIPS
}

Raymond Fisman

Mayank Raturi

Working Paper 9659

http://www.nber.org/papers/w9659

\author{
NATIONAL BUREAU OF ECONOMIC RESEARCH \\ 1050 Massachusetts Avenue \\ Cambridge, MA 02138 \\ April 2003
}

We thank Richard Caves, Bruce Greenwald, Karen Fisman, Victor Goldberg, Richard Zeckhauser, participants at the NBER Corporate Finance Summer Institute, the editor, and two anonymous referees for extremely helpful comments and advice. We are particularly grateful to Mike Riordan and Eslyn JeanBaptiste for many enlightening conversations. The views expressed herein are those of the authors and not necessarily those of the National Bureau of Economic Research.

(C)2003 by Raymond Fisman and Mayank Raturi. All rights reserved. Short sections of text not to exceed two paragraphs, may be quoted without explicit permission provided that full credit including @notice, is given to the source. 
Does Competition Encourage Credit Provision? Evidence from African Trade Credit Relationships

Raymond Fisman and Mayank Raturi

NBER Working Paper No. 9659

April 2003

JEL No. L12, L14

\begin{abstract}
Previous work has claimed that monopoly power facilitates the provision of credit, since monopolists are better able to enforce payment. Here, we argue that if relationship-specific investments are required by borrowers to establish creditworthiness, monopoly power may reduce credit provision because hold up problems ex post will deter borrowers from investing in establishing creditworthiness. Empirically, we examine the relationship between monopoly power and credit provision, using data on the supply relationships of firms in five African countries. Consistent with the upfront investment story, we find that monopoly power is negatively associated with credit provision, and that this correlation is stronger in older supplier relationships. Because the data include several observations per firm, we are able to utilize firm fixed-effects, thus netting out unobserved firm characteristics that may have been driving results in earlier studies.
\end{abstract}

Raymond Fisman

823 Uris Hall

Columbia University

New York, NY 10027

and NBER

rf250@columbia.edu

Mayank Raturi

Swiss Re

55 East 52nd Street

New York, NY 10055

mayank_raturi@swissre.com 
There exists a substantial economic literature, both theoretical and empirical, examining the relationship between competition and credit provision. This body of research has generally conjectured a positive association between monopoly power and the provision of credit, because of a monopolist's ability to enforce payment by threatening to cut off the supply of future credit or goods. By contrast, suppliers of credit in competitive markets will face difficulties in enforcing payment, since buyers may simply renege and move on to other creditors. Petersen and Rajan (1997) use this argument in their study of supplier credit in the United States, and McMillan and Woodruff (1999) also utilize this reasoning in looking at supplier credit relationships in Vietnam. ${ }^{1}$ These conclusions, however, are potentially in conflict with claims that are often made by managers in developing economies about the actual provision of credit from suppliers. For example, during a recent series of firm-level surveys in several SubSaharan African countries, we asked owners and managers why they provided goods on credit. A common response was that if a buyer were not provided with trade credit, he would threaten to make his purchases from an alternative supplier, suggesting that competition may increase a supplier's willingness to provide credit.

In this paper, we provide an economic explanation that captures the intuition, suggested above, that ex ante competition may encourage credit provision, because provision of credit is an effective means of preventing customer switching. Our explanation is based on the observation that in many cases, effort must be exerted by the borrower in order to establish creditworthiness before any credit is provided. Where such non-contractible, upfront investments are required, it is no longer clear that monopoly power increases credit provision, since the necessary investments will not be made if the

\footnotetext{
${ }^{1}$ Closely related theories are used by Petersen and Rajan (1995) and Bergstresser (2002) to argue for the benefits of monopoly power in banking markets.
} 
buyer anticipates that all surplus will be extracted by the monopolist ex post. Some bargaining power, through the threat of leaving the relationship, is required to induce the buyer to make the required initial investment. At the same time, this upfront investment creates a switching cost for buyers, since the non-contractible investment must be made with every new supplier, hence diminishing the relative value of outside options. This lock-in mitigates concerns of non-payment in competitive markets, thereby reducing the relative advantage of monopolists in supplying credit.

In the empirical section that is the primary focus of this paper, we test for the effect of product market competition on the decision to provide trade credit using data from firms in five African countries. ${ }^{2}$ We find a strong, robust, and positive relationship between supplier competition and credit provision in regressions that include firm fixedeffects. We provide some further evidence in support of the upfront investment model that we propose, with regressions showing that the higher likelihood of competitive firms obtaining credit occurs primarily in relationships that have existed for several years, and have therefore had time to allow for creditworthiness to be established.

This paper is related to a number of literatures in economics. Most obviously, we build on previous work in the area of relational contracting, which often uses trade credit access as a proxy for interfirm trust. Recent significant contributions to this literature include Fafchamps (2000), and particularly McMillan and Woodruff (1999). The results of this paper are also relevant for both the theoretical and empirical literatures on trade credit more generally (see Petersen and Rajan, 1997, for a recent survey). Many papers in this area already consider the importance of relationship-building in leading to credit

\footnotetext{
2 Our paper examines the relationship between credit provision and product market competition for SubSaharan African firms because of the fineness of the data available through the RPED survey. One concern might be that this is a region where contracting is acutely difficult, and that our results would not hold in more moderate contracting environments. We find evidence to the contrary, based on U.S. data: for the
} 
provision, often by focusing on suppliers' preferential access to information about their customers (see, for example, Biais and Gollier, 1997). Finally, our research relates to the emerging literature on the effect of ownership concentration on the lending policies of banks, as in the work of Bergstresser (2002) and Petersen and Rajan (1995).

The rest of this paper proceeds as follows: In Section 1, we elaborate on the intuition described in the introduction on why competition may increase credit provision. The data used in this paper are described in Section 2. In Section 3, we provide our empirical results, as well as a discussion of potential omitted variable bias. Finally, we conclude in Section 4 with some implications of our results.

\section{Competition and Credit Provision: Theoretical Overview}

The risk of non-payment of supplier credit stems from two sources: default from firms that legitimately lack the financial resources to make payments, and the deliberate nonpayment by firms that hope to 'steal' the value of credit owing. The latter difficulty may be mitigated by court-enforced contracts, and in their absence, implicit enforcement through the seller's threat of supply interruption. The effectiveness of this threat, as noted by Peterson and Rajan (1997), is diminished if there are alternative suppliers of the good, since a 'dishonest' buyer may renege on payment, and subsequently switch to a new supplier (as long as there is not effective diffusion of information about defaults). This is the traditional argument that leads to the prediction that monopolists will be more likely to provide credit, since they are better able to punish non-payment. ${ }^{3}$

sample of firms in the WorldScope database, we find that accounts receivable are negatively correlated with industry concentration. Results available from the authors.

${ }^{3}$ Petersen and Rajan (1997) also note that if the buyer purchases only a relatively small percentage of the supplier's output, then this will also increase the supplier's ability to enforce repayment. 
The novel element that we introduce here is the idea that a buyer may need to exert effort to establish creditworthiness prior to the provision of credit. ${ }^{4}$ This upfront effort may be necessary to mitigate risk of both deliberate and unintentional default. To the extent that honesty characterizes a buyer's 'type' (honest versus dishonest) this upfront learning may attenuate concerns of deliberate default. In addition, a buyer will be required to demonstrate that his finances are sound, to deal with concerns of default driven by poor future business prospects. To the extent that the benefits generated by these investments only occur later (after the provision of credit begins), there will be a standard hold-up problem that discourages the initial investment. These concerns will be particularly acute for buyers facing monopolistic suppliers, since the bargaining power accorded to monopolistic sellers will allow them to extract all ex post surplus. Recognizing this, the buyer will not make the upfront investments required to establish creditworthiness, and as a result, no credit will be given. By contrast, under competition, the buyer has the possibility of starting a relationship with a new supplier. This outside option allows the buyer to obtain a share of the generated surplus, and hence creates an incentive for the buyer to invest in establishing creditworthiness ex ante.

Additionally, the relationship specificity of these investments creates a switching cost that also mitigates concerns of deliberate non-payment in competitive markets: a firm that reneges on credit payments must find a new supplier, and make its upfront investment in establishing creditworthiness once again. Thus, in the spirit of Williamson (1971), this lock-in provides a supplier in an ex ante competitive market with enough market power ex post to prevent cheating by buyers.

\footnotetext{
${ }^{4}$ Effort will also likely be required of the supplier. This will only reinforce the advantage conferred on monopolists in credit provision, as sellers with monopoly power will be better positioned to recoup these upfront investments ex post due to greater bargaining power. Since our focus is on the elements to credit provision that may generate the opposite relationship between monopoly power and credit, we concentrate on buyer investments.
} 
To summarize, the need for buyer investments before credit is given simultaneously reduces demand for credit in monopolistic markets because of fear on the part of buyers of expropriation ex post, and increases the willingness of suppliers in competitive markets to provide goods on credit, because the lock-in generated by the relationship specificity of these investments creates switching costs that reduce concerns of non-payment. ${ }^{5}$

The preceding discussion is premised on the assumption that buyers must make upfront relationship-specific investments in order to establish their creditworthiness. While we did not collect data on supplier relationship-building specifically, there are anecdotal reports that are consistent with this assumption. Prior to the provision of credit, buyers are required to solicit referrals, and open their accounts and operations to greater scrutiny so as to increase transparency. Many of the firms that we interviewed did not keep any formal accounts at all: in this case, the only way that the credibility required for credit provision may be established is through relationship-building. Furthermore, an additional element of lock-in may derive from the waiting period that is typically required for the buyer and seller to gain familiarity with one another, prior to the provision of credit. ${ }^{6}$ Overall, this gradual establishment of credibility yields a corollary prediction. Suppose that it is true that credit will only be provided in competitive markets after an initial period of learning. Then among very young relationships, we should not see a higher rate of credit provision in more competitive industries. The greater likelihood of obtaining credit should only occur in older relationships, where

\footnotetext{
${ }^{5}$ In an extended version of this paper, we include a model of one-sided investment with the potential for nonpayment that formalizes the intuition discussed in this section. This model is available from the authors, but is omitted here in the interests of space.

${ }^{6}$ This is consistent with the positive relationship between length of relationship and credit provision that we report below. Also, it is consistent with several recent theoretical models in which, in the presence of 'non-cooperative types', relationships are characterized by the gradual build-up of trust (see, for example,
} 
creditworthiness and trust have been established. In Section 4, we provide empirical results consistent with this ancillary prediction. ${ }^{7}$

\section{Data}

The data used in this paper come from surveys administered by the Regional Program on Enterprise Development (RPED) at the World Bank during 1992-95, to five former

British colonies in Sub-Saharan Africa (Ghana, Kenya, Tanzania, Zambia, and

Zimbabwe). The firms were chosen to reflect a size-weighted representative sample, by industry, of the universe of firms in each country.

While there are always concerns of data quality from surveys of this type, we believe that they are minimal with regard to the analyses in this paper. Most importantly, errors generally arise from misreporting or mismeasurement of accounting data, such as sales; capital; expenses. All critical regressions below do not require these data as controls, largely because of our fixed effects specifications. In fact, almost all of our results are derived using only very simple, survey-based variables that are relatively straightforward for the survey respondents to estimate. Deliberate misreporting, while often a concern, is unlikely to be driving our results. First, the survey was carried out by an independent organization (i.e., without government affiliations), so there was less incentive for managers to mislead or withhold information. Furthermore, it is unclear why misreporting would be systematically correlated with any of the variables that we use.

Ghosh \& Ray, 1996). In the context of trading relationships, this suggests that the provision of credit will develop slowly, only as the supplier comes to learn more about the buyer and his 'type'.

${ }^{7}$ We also note that the lock-in derived from credit relationships is likely to be intensified by adverse selection among firms searching for new suppliers, since suppliers will be more likely to allow lapses in relationships with firms that are poor credit risks to begin with. This would similarly make it difficult for suppliers to try to lure buyers away from their competitors - presumably, 'low-quality' buyers would be the first to be let go by their current suppliers. 
The data contain information on the firm's relationships with the primary supplier of each of its three most important inputs. Thus, there are up to three observations per firm. The form of payment was among the relationship-specific characteristics collected in the survey; virtually all relationships were characterized by credit or cash transactions, with a few reports of advance payment. These data were used to construct the dummy variable CREDIT, which takes on a value of one if purchases with a particular supplier were largely credit based. This will be the dependent variable in most of what follows.

To proxy for the extent of product market competition, we utilize responses to the question, "Is this the only possible supplier available for this raw material or input?" These responses were used to construct the variable COMPETITION, which takes on a value of one if there is more than one supplier available to provide the materials purchased; this variable reflects whether the supplier has monopoly power.

There are several relationship-level characteristics that may affect credit access and could be correlated with supplier market structure, and hence must be included as controls. Particularly important is the length of relationship with the supplier: If, as suggested above, trust develops gradually, length of relationship will be an important determinant of credit provision. We therefore include the reported length of the relationship with a given supplier in years $(L E N G T H)$ as a control. ${ }^{8}$

Frequency of interaction may also be an important predictor of credit access: frequent transactions will put a supplier in a better position to retaliate quickly for nonpayment, suggesting a positive relationship between credit provision and frequency of purchase. From a demand perspective, there are two effects. On the one hand, there may be less need for credit between parties that transact frequently, since making purchases in

\footnotetext{
${ }^{8}$ In the simplest specification, including only COMPETITION and firm fixed effects, the coefficient on COMPETITION is only slightly smaller than in the results given below, and is still significant at the 1 percent level.
} 
small batches requires less capital; this argues for a negative relationship. However, since credit may be most useful in lowering transactions costs (by aggregating bills) when purchases are frequent, more credit may be used in high frequency relationships. Overall, the predicted effect is ambiguous. We define FREQUENCY as the frequency with which purchases were made from a given supplier. These values range from daily $($ FREQUENCY $=6)$ to yearly $($ FREQUENCY $=0){ }^{9}$

Finally, there is a substantial literature relating social ties to credit provision. In particular, Fafchamps (2000) has argued that ethnic networks may be an important determinant of credit provision. To control for this effect, we included the variable ETHNIC, a dummy variable that takes on a value of one if both the firm and its supplier were Asian, or both were European. This variable is not available for Ghanaian firms.

Since we will be using a firm fixed-affects specification in most regressions, firmlevel characteristics are of secondary importance. However, for the purposes of comparison with previous work, we report some firm-level regressions and therefore require a number of additional covariates. The primary concern in firm-level regressions is controlling for firm quality and reputation, which are surely correlated with credit access. The proxies for reputation/quality that we use are the following:

SIZE - Following on previous work using the RPED data, we use total employment, given by (full-time workers) $+0.5^{*}$ (part-time workers), as a measure of firm size. OVERDRAFT- dummy variable; takes on a value of one if the firm has access to overdraft facilities. $A G E$ - firm's age.

\footnotetext{
${ }^{9}$ Firms were given the option of responding that the frequency of interaction was "Occasional" - we omit observations where this rather non-specific response was given in regressions involving the variable FREQUENCY.
} 
Additional controls that are commonly employed include ethnicity and gender dummies; hence, we include the following: $A S I A N$ - dummy variable that takes on a value of one if the firm's owner is of Asian descent. This variable is not available for Ghanaian firms. $E U R O$ - dummy variable that takes on a value of one if the firm's owner is of European descent. This variable is not available for Ghanaian firms.

GENDER - dummy variable equal to one if the firm's owner is female.

Finally, since subsidiaries of larger firms may obtain goods on credit from their parent companies, or may have the parent company act as guarantor, we include SUBSIDIARY, a dummy variable denoting whether the firm is a subsidiary of a conglomerate. A summary of all data definitions is given in the Data Appendix. Industry-country dummies are also included in the random effects regressions. There are four broad industries covered by the survey: Food Processing; Textiles and Clothing; Wood and Furniture; and Metal Products. Since our sample contains five countries, this yields a total of nineteen dummy variables.

The original sample included data on 1045 firms; of these, 19 did not report any information on their supplier relationships, and were thus dropped from the sample. The remaining 1026 firms included data on a total of 2494 supplier relationships. Relationship-level observations were dropped where information on the length of the relationship (174) or the competitiveness of the supplier market (9) was missing (number of observations dropped in parentheses; deletions done sequentially). This yielded a sample of 960 firms with 2311 relationships. For the random effects regressions, SIZE was not available for some firms, thereby reducing the sample in these regressions to 2202 observations. Basic summary statistics for the firms are listed in Table 1a. 
Firms for which there is no variation in credit access are problematic for withinfirm binary choice regressions. We follow Chamberlain (1986), in running conditional logit regressions, which automatically excludes firms without variation in CREDIT. Thus, these regressions are limited to a subsample of observations consisting of 188 firms with 527 relationships. Summary statistics of this smaller sample are listed in Table $1 \mathrm{~b}$.

\section{Results}

In the analyses that follow, we utilize two different models: random effects logit, and conditional fixed effects logit (as developed by Chamberlain, 1980). As already mentioned above, the sample size will be considerably smaller for the fixed effects specifications.

\section{Random Effects Model}

As always, there are concerns that the random effect will be correlated with some relationship-level characteristics that reflect firm quality. We include standard firm-level controls (described above in the data section), and also the means of our relationshiplevel variables, as suggested by Chamberlain (1984). This leads to the following specification:

$$
\begin{aligned}
& \mathrm{P}\left(\text { CREDIT }_{s i}=1\right)=\Lambda\left(\beta_{1} * \operatorname{LENGTH}_{s i}+\beta_{2}{ }^{*} \text { COMPETITION }_{s i}+\beta_{3}{ }^{*} \text { LENGTH }_{s i}{ }^{*} \text { COMPETITION }_{s i}\right. \\
& +\beta_{4} * \text { FREQUENCY } Y_{s i}+\beta_{5} * \text { ETHNIC }_{S i}+\beta_{6} * \operatorname{avg}(\text { LENGTH })_{\mathrm{i}}+\beta_{7} * \operatorname{avg}(\text { COMPETITION })_{\mathrm{i}} \\
& +\beta_{8} * \operatorname{avg}(\text { FREQUENCY })_{\mathrm{i}}+\beta_{9} * \operatorname{avg}\left(\text { ETHNIC }_{\mathrm{i}}+\beta_{10} * \log \left(\text { SIZE }_{i}\right)+\beta_{11} * \text { OVERDRAFT },\right. \\
& \left.+\beta_{12} * A G E_{i},+\beta_{13} * E U R O_{i},+\beta_{13} * \operatorname{ASIAN}_{i},+\operatorname{INDUSTRY}_{i}+\operatorname{COUNTRY}_{i}+\eta_{i}+\varepsilon_{s i}\right)
\end{aligned}
$$


where $i$ is a firm index and $s$ is a relationship index; INDUSTR $\boldsymbol{Y}_{i}$ is a vector of industry dummies and $\boldsymbol{C O U N T R} \boldsymbol{Y}_{i}$ is a vector of country dummies; $\Lambda($.$) is the logistic function; \eta_{\mathrm{i}}$ is a firm-specific random effect, and $\varepsilon_{\mathrm{si}}$ is the error term.

Table 2 lists the results. The coefficient on the variable of primary interest, COMPETITION, is positive, and generally significant at the 5 percent. The coefficient's size, 0.9, implies that for a firm with 'average' characteristics, the probability of obtaining credit increases from 40 to 60 percent in switching from a monopolistic to a competitive supplier market, holding buyer characteristics constant. This is an economically large effect; based on a comparison with the coefficient on $L E N G T H$, the effect of COMPETITION is analogous to the difference in credit access between a new relationship and a relationship that has existed for more than 20 years already. By contrast, the coefficient on $\operatorname{avg}(C O M P E T I T I O N)$ is never significant, and does not have a consistent sign across regressions. ${ }^{10}$

In the previous discussion, we also claimed that lock-in should lead to greater provision of credit in competitive markets only after an initial period during which creditworthiness is established. A prediction stemming from this observation is that competition should matter more among older relationships, i.e., we expect that the coefficient on the interaction term $L E N G T H^{*} C O M P E T I T I O N$ should be positive. Results in support of this prediction are listed in column (5). The coefficient on the uninteracted COMPETITION term is only slightly greater than zero, implying that for new

\footnotetext{
10 There are numerous reasons that could account for this relating to unobserved heterogeneity across firms, which highlights the importance of having within-firm variation. For example, firms in more densely packed industrial areas may be more likely to have competitive suppliers. Such areas may also have more effective legal enforcement or informational diffusion mechanisms leading to implicit enforcement, both of which could facilitate the provision of credit. Conversely, firms with monopolistic suppliers may be in isolated areas, where enforcement is easier due to the relatively small size of the business community. Hence the ambiguous observed relationship between avg(COMPETITION) and CREDIT. Not surprisingly, therefore, if the data are collapsed into a single observation per firm, and the regressions run using a simple cross-section with avg(CREDIT) as the dependent variable, the effect of competition appears to be insignificant.
} 
relationships (i.e., $L E N G T H=0$ ), the probability of obtaining credit is virtually identical for both competitive and monopolistic suppliers.

The other coefficients in Table 2 are, for the most part, as expected. Among the relationship specific variables: the coefficient on $L E N G T H$ is positive and generally significant, consistent with the idea that there is a gradual build-up of trust that precedes the provision of credit. In the regressions that include FREQUENCY, its coefficient is positive and marginally significant, while the coefficient on $\operatorname{avg}(F R E Q U E N C Y)$ is negative. One interpretation of these results is the following: frequent interaction makes it easier to punish non-payment, and should thus promote the provision of credit, hence the positive coefficient on FREQUENCY. On the other hand, firms that interact frequently with their suppliers are more likely to be credit constrained, and hence poor credit risks (thus the negative coefficient on avg(FREQUENCY)). The coefficient on ETHNIC, which directly measures the presence of ethnic supplier ties, is positive and marginally significant. For the firm-level variables, firm size, a good proxy for a company's reliability and reputation, is large and significant. The coefficient on OVERDRAFT is also positive and strongly significant. While it might be tempting to interpret this as representing a complementarity between formal (bank) and informal (trade credit) financing, this would not be appropriate - access to overdraft facilities is probably a signal of (unobserved) firm quality, which might also account for a firm's trade credit access. $A G E$ is relatively small in size and significance, which is surprising given that the age of an establishment should be a reasonably good proxy for its reliability in repaying its debts (though perhaps it does not add any information after controlling for LENGTH). Finally, consistent with previous work in this area, the coefficients on the two ethnicity dummies are also positive, and the Asian dummy is significant (see, for example, Fafchamps, 2000). While this has often been interpreted as resulting from 
ethnic networks that facilitate contract enforcement, it may also be driven by unobserved heterogeneity across ethnic groups (see Fisman, 2003).

\section{Fixed Effects Model}

All of the preceding regressions were repeated using Chamberlain's (1980) conditional fixed-effects model. Because the maximum likelihood estimation in this case is conditional on the total number of suppliers from which a firm receives goods on credit, all observations for which there is no within firm variation in CREDIT drop out of the maximum likelihood expression. This reduces the sample size to 188 firms with 527 relationships). Our fixed-effects specification is as follows:

$$
\begin{gathered}
\mathrm{P}\left(\text { CREDIT }_{s i}=1\right)=\Lambda\left(\beta_{1}^{*} \text { LENGTH }_{s i}+\beta_{2} * \text { COMPETITION }_{s i}+\beta_{3} * \text { LENGTH }_{s i} * \text { COMPETITION }_{s i}\right. \\
+\beta_{4}{ }^{*} \text { FREQUENCY } \\
s i
\end{gathered}
$$

The results are listed in Table 3; the coefficients are very similar to those obtained with the random effects model, suggesting that the firm-level controls do a reasonable job of controlling for unobserved quality as it may be correlated with relationship-level regressors. The coefficient on COMPETITION is again positive, and significant at 1 percent in the basic regression; its size is unaffected by the inclusion of additional controls, though it significance diminishes somewhat as the sample size is reduced. ${ }^{11}$ Note that the size of the coefficient on COMPETITION is very similar to its size in the random effects regressions. Similarly, the interaction term $L E N G T H^{*} C O M P E T I T I O N$ is of comparable (though marginal smaller) magnitude, though it is no longer significant at

\footnotetext{
${ }^{11}$ To the extent that the coefficient changes across specifications, this is actually due to changes in the sample, rather than the inclusion of additional controls.
} 
conventional levels. The other coefficients are also very similar to their counterparts in the random effects regressions.

\section{Robustness}

There are two basic concerns regarding the robustness of our results: the omission of supplier characteristics correlated with supplier competition; and alternative explanations for the positive relationship between COMPETITION and CREDIT. Below, we provide a brief discussion of each of these issues.

The major concern of omitted variable bias results from the lack of control for supplier size, which would almost certainly be correlated with the decision to provide credit, and also competition. However, the omission of this variable most likely biases our results towards zero, since monopolists are probably larger firms, and larger firms are probably more likely to grant credit. We may examine this possibility to a limited degree with the available data, since it gives us the rank ordering of the value of purchases from each of the three suppliers. We define SUPPLIER SIZE as this rank ordering (i.e., SUPPLIER SIZE = 1 for the most important supplier; etc.). Assuming that suppliers that provide a larger volume of inputs are larger firms, adding this variable should be a proxy for supplier size. When SUPPLIER SIZE is included as a regressor, its coefficient is of the predicted sign and very significant; once supplier size is controlled for in this admittedly imprecise manner, the coefficient on COMPETITION increases (to about $0.95) .^{12}$

\footnotetext{
12 Another concern may be heterogeneity across countries. In particular, there are vast differences in key variables, specifically access to credit, which goes from 0.08 (Tanzania) to almost 0.7 (Zimbabwe). To ensure that no particular country is driving our result, we repeated our analyses for each country individually. The coefficient on COMPETITION was positive in all countries (except Tanzania, where there were insufficient observations to calculate standard errors ), taking on values from 0.16 to 0.95 . We cannot reject the hypothesis of equal coefficients, though any test of such a hypothesis is statistically very weak.
} 
The principal alternative explanation for the positive correlation between COMPETITION and CREDIT requires that we depart from the standard profitmaximizing view of the firm. In particular, it involves the assumption that the investment necessary for credit provision requires effort on the part of the supplier, and that monopolists prefer the 'quiet life' and therefore do not exert this effort. While this is certainly plausible, we do not find any evidence in our data to suggest that monopolists fail to exert costly effort along other dimensions. For example, using data on product market competition, we find that greater competition is negatively correlated with both investment and advertising as a fraction of total sales, though these correlations are not significant. To the extent that these are also costly investments required to generate future profits, it is at least suggestive that firms in less competitive markets are not opting for the quiet life.

\section{Relation to earlier literature}

Our results apparently contradict those of McMillan and Woodruff (2000), who examine the determinants of credit access in Vietnam. They report that in their sample, there is greater provision of credit for firms that would have trouble finding alternative suppliers, i.e., firms whose suppliers do not face competition. This discrepancy may further highlight the value of having within-firm variation. Note that in some specifications, the random effects regressions produce a negative sign on $\operatorname{avg}(C O M P E T I T I O N)$, i.e., firms that are generally in competitive environments are less likely to obtain credit. This is a firm-level (as opposed to relationship-level) effect that would be a part of McMillan and Woodruff's measure of competition. If it were to dominate the competitive-relationship effect, this could account for the difference in results. 
Our results also contrast with those of Petersen and Rajan (1995). The basic difference is that their data come from the U.S., where formal financial institutions are far more prevalent than in sub-Saharan Africa. Also, with active credit rating agencies, information on credit histories would be readily available. In other words, one would not expect credit to be a primary means of locking in customers in the markets studied by Petersen and Rajan. Also, there is the fact that the Peterson and Rajan are looking at lending institutions, so credit is not the hook to obtain and keep customers for some other product. Rather, credit is the product, so it is peculiar to think about any distinction between price competition and credit competition in this context.

\section{Conclusion}

Previous work on credit provision has claimed that monopoly power facilitates the provision of credit, since monopolists are better able to capture the surplus resulting from credit relationships. In this paper we argue that if relationship-specific investments are required by the borrower to establish creditworthiness before any credit is provided, monopolists may provide less credit, since hold up problems ex post will deter borrowers from investing in establishing creditworthiness. Consistent with the upfront investment story, we find that monopoly power is negatively associated with credit provision, and that this correlation is stronger in older supplier relationships.

Note, however, that the welfare and policy implications of the development of credit relationships are not entirely clear. We have argued that the primary reason that competition may promote credit provision is that it permits firms in competitive markets to gain some degree of market power over their customers. To the extent that this allows a firm to extract rents through monopoly pricing, some of the benefits of competition may be attenuated. In more developed countries, this problem of credit 'lock in' is 
mitigated by the existence of credit rating agencies that track companies' credit histories. Such organizations are only beginning to emerge in the less developed economies from which we draw our data. Our results suggest that the development of such institutions could be a tremendous boon for buyers - if the flow of information required for credit provision could be provided for general (rather than relationship-specific) use, firms might obtain credit from a broader set of suppliers, and at the same time diminishing the monopoly power that proprietary credit relationships may engender. 


\section{Data Appendix}

\section{$\underline{\text { Relationship Variables }}$}

CREDIT - dummy variable denoting whether purchases with a particular supplier were largely credit based.

COMPETITION - dummy variable denoting whether there is more than one supplier available to provide the materials purchased.

$L E N G T H$ - the reported length of the relationship with a given supplier, in years.

FREQUENCY - the frequency with which purchases were made from a given supplier. These values range from daily (FREQUENCY $=6$ ) to yearly $($ FREQUENCY=0).

ETHNIC - dummy variable that takes on a value of one if both the firm and its supplier were Asian, or both were European.

\section{$\underline{\text { Firm Variables }}$}

SIZE - total firm employment, given by (full-time workers) $+0.5 *$ (part-time workers).

OVERDRAFT- dummy variable denoting whether the firm has access to overdraft facilities.

$A G E$ - firm's age.

$A S I A N$ - dummy variable that takes on a value of one if the firm's owner is of Asian descent.

$E U R O$ - dummy variable that takes on a value of one if the firm's owner is of European descent.

GENDER - dummy variable equal to one if the firm's owner is female.

SUBSIDIARY - dummy variable denoting whether the firm is a subsidiary of a conglomerate. 


\section{References}

Bergstresser, Daniel. "Market concentration and commercial bank loan portfolios." manuscript, Harvard Business School, 2002.

Biais, Bruno and Christian Gollier. "Trade Credit and Credit Rationing." Review of Financial Studies, 10 (4), Winter 1997, pp. 903-937.

Chamberlain, Gary. "Analysis of Covariance with Qualitative Data." Review of Economic Studies, 47, 1980, pp. 225-238.

Chamberlain, Gary. "Panel Data." Handbook of Econometrics, Volume II, Zvi Griliches and Michael D. Intriligator (eds.). New York: North-Holland, 1984, pp. 12481318.

Greene, William H. Econometric Analysis, 4th edition, Prentice-Hall: New Jersey, 2000.

Fafchamps, Marcel. "Trade Credit in Zimbabwean Manufacturing." World Development, 25 (5), July 1997, pp. 795-815.

Fafchamps, Marcel. "Ethnicity and Credit in African Manufacturing." Journal of Development Economics, 61(1), February 2000, 205-35.

Fisman, Raymond J., "Ethnic Ties and the Provision of Credit: Relationship-level Evidence from African Firms" Berkeley Economics Journal: Advances in the Economics and Growth of Developing Areas, Vol. 1, Iss. 1, 2003, http://www.bepress.com/bejegda/advances/voll/iss1/art1.

Ghosh, Parikshit and Debraj Ray. "Cooperation in Community Interaction without Information Flows." Review of Economics Studies, 63 (3), July 1996, pp. 491-519.

MacMillan, John, and Christopher Woodruff. "Interfirm Relationshipss and Informal Credit in Vietnam." Quarterly Journal of Economics, 114(4), November 1999, pp. 1285-1320.

Petersen, Mitchell A. and Raghuram G. Rajan. "The Effect of Credit Market Competition on Lending Relationships." Quarterly Journal of Economics, 110 (2), May 1995, pp. 407-43.

Petersen, Mitchell A. and Raghuram G. Rajan. "Trade Credit: Theories and Evidence." Review of Financial Studies, 10(3), Fall 1997, pp. 661-691.

Williamson, Oliver E. "The Vertical Integration of Production: Market Failure Considerations," American Economic Review, May 1971, 61, 112-23. 
Table 1a: Summary Statistics

\begin{tabular}{|c|c|c|c|c|c|c|}
\hline & $\begin{array}{c}\text { Full } \\
\text { Sample }\end{array}$ & Ghana & Kenya & Tanzania & Zambia & Zimbabwe \\
\hline \multicolumn{7}{|l|}{$\underline{\text { Firm Variables }}$} \\
\hline Size & $\begin{array}{r}122 \\
(940)\end{array}$ & $\begin{array}{l}63.36 \\
(143)\end{array}$ & $\begin{array}{r}87.1 \\
(205)\end{array}$ & $\begin{array}{r}98.9 \\
(207)\end{array}$ & $\begin{array}{l}82.31 \\
(197)\end{array}$ & $\begin{array}{r}271.72 \\
(188)\end{array}$ \\
\hline AGE & $\begin{array}{l}17.93 \\
(959)\end{array}$ & $\begin{array}{l}15.23 \\
(145)\end{array}$ & $\begin{array}{l}17.94 \\
(210)\end{array}$ & $\begin{array}{l}14.99 \\
(208)\end{array}$ & $\begin{array}{l}17.66 \\
(201)\end{array}$ & $\begin{array}{l}23.36 \\
(195)\end{array}$ \\
\hline OVERDRAFT & $\begin{array}{r}0.46 \\
(954)\end{array}$ & $\begin{array}{r}0.25 \\
(144)\end{array}$ & $\begin{array}{r}0.63 \\
(209)\end{array}$ & $\begin{array}{r}0.25 \\
(208)\end{array}$ & $\begin{array}{r}0.46 \\
(202)\end{array}$ & $\begin{array}{r}0.69 \\
(191)\end{array}$ \\
\hline SUBSIDIARY & $\begin{array}{r}0.03 \\
(960)\end{array}$ & $\begin{array}{r}0.01 \\
(145)\end{array}$ & $\begin{array}{r}0.01 \\
(210)\end{array}$ & $\begin{array}{r}0.02 \\
(208)\end{array}$ & $\begin{array}{r}0.01 \\
(202)\end{array}$ & $\begin{array}{r}0.1 \\
(195)\end{array}$ \\
\hline ASIAN & $\begin{array}{r}0.3 \\
(703)\end{array}$ & & $\begin{array}{r}0.53 \\
(194)\end{array}$ & $\begin{array}{r}0.24 \\
(165)\end{array}$ & $\begin{array}{r}0.27 \\
(173)\end{array}$ & $\begin{array}{r}0.13 \\
(171)\end{array}$ \\
\hline EURO & $\begin{array}{r}0.15 \\
(703)\end{array}$ & & $\begin{array}{r}0.01 \\
(194)\end{array}$ & $\begin{array}{r}0 \\
(165)\end{array}$ & $\begin{array}{r}0.13 \\
(173)\end{array}$ & $\begin{array}{r}0.47 \\
(171)\end{array}$ \\
\hline GENDER & $\begin{array}{r}0.87 \\
(751)\end{array}$ & $\begin{array}{r}0.76 \\
(119)\end{array}$ & $\begin{array}{r}0.92 \\
(183)\end{array}$ & $\begin{array}{r}0.94 \\
(162)\end{array}$ & $\begin{array}{r}0.89 \\
(156)\end{array}$ & $\begin{array}{r}0.81 \\
(131)\end{array}$ \\
\hline \multicolumn{7}{|c|}{$\underline{\text { Relationship Variables }}$} \\
\hline CREDIT & $\begin{array}{r}0.32 \\
(2311)\end{array}$ & $\begin{array}{r}0.32 \\
(306)\end{array}$ & $\begin{array}{r}0.4 \\
(447)\end{array}$ & $\begin{array}{r}0.08 \\
(492)\end{array}$ & $\begin{array}{r}0.16 \\
(525)\end{array}$ & $\begin{array}{r}0.63 \\
(541)\end{array}$ \\
\hline LENGTH & $\begin{array}{r}10.23 \\
(2311)\end{array}$ & $\begin{array}{r}6.5 \\
(306)\end{array}$ & $\begin{array}{r}8.38 \\
(447)\end{array}$ & $\begin{array}{r}8.84 \\
(492)\end{array}$ & $\begin{array}{r}9.45 \\
(525)\end{array}$ & $\begin{array}{l}15.87 \\
(541)\end{array}$ \\
\hline COMPETITION & $\begin{array}{r}0.83 \\
(2311)\end{array}$ & $\begin{array}{r}0.94 \\
(306)\end{array}$ & $\begin{array}{r}0.87 \\
(447)\end{array}$ & $\begin{array}{r}0.83 \\
(492)\end{array}$ & $\begin{array}{r}0.8 \\
(525)\end{array}$ & $\begin{array}{r}0.78 \\
(541)\end{array}$ \\
\hline ETHNIC & $\begin{array}{r}0.08 \\
(1478)\end{array}$ & & $\begin{array}{r}0.14 \\
(338)\end{array}$ & $\begin{array}{r}0.05 \\
(385)\end{array}$ & $\begin{array}{r}0.04 \\
(447)\end{array}$ & $\begin{array}{r}0.11 \\
(308)\end{array}$ \\
\hline FREQUENCY & $\begin{array}{r}2.38 \\
(1903) \\
\end{array}$ & $\begin{array}{r}2.23 \\
(177) \\
\end{array}$ & $\begin{array}{r}1.99 \\
(431) \\
\end{array}$ & $\begin{array}{r}2.76 \\
(379) \\
\end{array}$ & $\begin{array}{r}2.56 \\
(431) \\
\end{array}$ & $\begin{array}{r}2.34 \\
(485) \\
\end{array}$ \\
\hline
\end{tabular}

Notes: Number of observations in parentheses. For variables definitions, please see Appendix. 
Table 1b - Summary Statistics with Sample Restricted to Firms with Variation in CREDIT

\begin{tabular}{l|rrrrrr}
\hline & Full & & & & & \\
& Sample & Ghana & Kenya & Tanzania & Zambia & Zimbabwe \\
\hline Firm Variables & & & & & & \\
Size & & & & & & \\
& 254.87 & 101.86 & 133.73 & 516.61 & 164.02 & 482.81 \\
AGE & $(188)$ & $(43)$ & $(31)$ & $(14)$ & $(47)$ & $(48)$ \\
& 22.41 & 17.44 & 17.53 & 23 & 25.74 & 26.72 \\
OVERDRAFT & $(188)$ & $(45)$ & $(32)$ & $(14)$ & $(47)$ & $(50)$ \\
SUBSIDIARY & 0.66 & 0.32 & 0.88 & 0.71 & 0.74 & 0.72 \\
& $(187)$ & $(44)$ & $(32)$ & $(14)$ & $(47)$ & $(50)$ \\
ASIAN & 0.04 & 0 & 0.03 & 0 & 0.02 & 0.1 \\
& $(188)$ & $(45)$ & $(32)$ & $(14)$ & $(47)$ & $(50)$ \\
EURO & 0.36 & & 0.66 & 0.63 & 0.44 & 0.05 \\
GENDER & $(111)$ & & $(29)$ & $(8)$ & $(32)$ & $(42)$ \\
Relationship Variables & 0.27 & & 0.03 & 0 & 0.19 & 0.55 \\
CREDIT & $(111)$ & & $(29)$ & $(8)$ & $(32)$ & $(42)$ \\
& 0.84 & 0.74 & 0.96 & 1 & 0.88 & 0.76 \\
LENGTH & $(123)$ & $(35)$ & $(27)$ & $(7)$ & $(25)$ & $(29)$ \\
& & & & & & \\
FOMEQUENCY & 0.5 & 0.47 & 0.49 & 0.5 & 0.45 & 0.57 \\
ETHNIC & $(527)$ & $(120)$ & $(86)$ & $(40)$ & $(135)$ & $(146)$ \\
& 11.03 & 5.86 & 7.87 & 9.93 & 10.27 & 18.29 \\
& $(527)$ & $(120)$ & $(86)$ & $(40)$ & $(135)$ & $(146)$ \\
& 0.84 & 0.96 & 0.83 & 0.88 & 0.91 & 0.67 \\
& $(527)$ & $(120)$ & $(86)$ & $(40)$ & $(135)$ & $(146)$ \\
& 0.07 & & 0.1 & 0 & 0.05 & 0.1 \\
& $(254)$ & & $(59)$ & $(24)$ & $(91)$ & $(80)$ \\
& 2.5 & 2.08 & 2.23 & 2.86 & 2.93 & 2.42 \\
& $(466)$ & $(81)$ & $(86)$ & $(37)$ & $(124)$ & $(138)$ \\
\hline
\end{tabular}

Notes: Number of observations in parentheses. For variables definitions, please see Appendix. 
Table 2: Access to Supplier Credit, Cross-sectional Logit Regressions

Dependent Variable: CREDIT

\begin{tabular}{|c|c|c|c|c|c|}
\hline 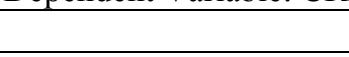 & $(1)$ & (2) & (3) & (4) & $(5)$ \\
\hline LENGTH & $\begin{array}{l}0.040 \\
(0.17)\end{array}$ & $\begin{array}{c}0.030 \\
(0.017)\end{array}$ & $\begin{array}{c}0.047 \\
(0.026)\end{array}$ & $\begin{array}{c}0.032 \\
(0.032\end{array}$ & $\begin{array}{l}0.005 \\
(0.02)\end{array}$ \\
\hline COMPETITION & $\begin{array}{c}0.946 \\
(0.337)\end{array}$ & $\begin{array}{c}0.920 \\
(0.346)\end{array}$ & $\begin{array}{c}1.216 \\
(0.507)\end{array}$ & $\begin{array}{c}1.292 \\
(0.562)\end{array}$ & $\begin{array}{l}0.234 \\
(0.47)\end{array}$ \\
\hline FREQUENCY & & $\begin{array}{c}0.160 \\
(0.092)\end{array}$ & $\begin{array}{c}0.237 \\
(0.133)\end{array}$ & $\begin{array}{c}0.255 \\
(0.155)\end{array}$ & $\begin{array}{l}0.046 \\
(0.02)\end{array}$ \\
\hline ETHNIC & & & $\begin{array}{c}1.19 \\
(0.738)\end{array}$ & $\begin{array}{c}1.217 \\
(0.770)\end{array}$ & \\
\hline $\log (\mathrm{SIZE})$ & $\begin{array}{c}0.777 \\
(0.093)\end{array}$ & $\begin{array}{c}0.699 \\
(0.095)\end{array}$ & $\begin{array}{c}0.901 \\
(0.152)\end{array}$ & $\begin{array}{c}0.460 \\
(0.188)\end{array}$ & $\begin{array}{c}0.793 \\
(0.094)\end{array}$ \\
\hline AGE & & & & $\begin{array}{c}0.020 \\
(0.022)\end{array}$ & \\
\hline avg (LENGTH) & $\begin{array}{l}-0026 \\
(0.023)\end{array}$ & $\begin{array}{l}0.0004 \\
(0.024)\end{array}$ & $\begin{array}{l}-0.025 \\
(0.036)\end{array}$ & $\begin{array}{l}-0.031 \\
(0.045)\end{array}$ & $\begin{array}{l}-0.024 \\
(0.023)\end{array}$ \\
\hline avg (COMPETITION) & $\begin{array}{c}0.004 \\
(0.561)\end{array}$ & $\begin{array}{c}0.048 \\
(0.579)\end{array}$ & $\begin{array}{l}-1.032 \\
(0.785)\end{array}$ & $\begin{array}{l}-0.809 \\
(0.868)\end{array}$ & $\begin{array}{c}0.15 \\
(0.563)\end{array}$ \\
\hline avg (FREQUENCY) & & $\begin{array}{l}-0.236 \\
(0.138)\end{array}$ & $\begin{array}{l}-0.360 \\
(0.200)\end{array}$ & $\begin{array}{l}-0.297 \\
(0.226)\end{array}$ & \\
\hline avg (ETHNIC) & & & $\begin{array}{l}0.867 \\
(1.01)\end{array}$ & $\begin{array}{c}0.315 \\
(1.027)\end{array}$ & \\
\hline SUBSIDIARY & & & & $\begin{array}{l}-0.107 \\
(2.97)\end{array}$ & \\
\hline OVERDRAFT & & & & $\begin{array}{c}0.870 \\
(0.525)\end{array}$ & \\
\hline GENDER & & & & $\begin{array}{c}1.695 \\
(0.817)\end{array}$ & \\
\hline ASIAN & & & & $\begin{array}{l}1.720 \\
(0.585)\end{array}$ & \\
\hline EURO & & & & $\begin{array}{c}0.986 \\
(0.822)\end{array}$ & \\
\hline $\begin{array}{l}\text { LENGTH* } \\
\text { COMPETITION }\end{array}$ & & & & & $\begin{array}{l}0.046 \\
(0.02)\end{array}$ \\
\hline $\begin{array}{l}\text { Chi2 } \\
\text { Log Likelihood } \\
\text { Obs. }\end{array}$ & $\begin{array}{c}172.75 \\
-933.37 \\
2202\end{array}$ & $\begin{array}{c}150.27 \\
-811.04 \\
1817\end{array}$ & $\begin{array}{c}92.99 \\
-439.21 \\
1177\end{array}$ & $\begin{array}{c}74.31 \\
-357.66 \\
1022\end{array}$ & $\begin{array}{c}171.23 \\
-931.12 \\
2202\end{array}$ \\
\hline
\end{tabular}

Notes: Standard Errors in Parentheses. All regressions have industry-country fixed effects. Please see Appendix for variable definitions. 
Table 3: Determinants of Credit Acess Firm Fixed Effects Logistic Regression Dependent Variable: CREDIT

\begin{tabular}{|c|c|c|c|c|}
\hline & (1) & (2) & (3) & (4) \\
\hline LENGTH & $\begin{array}{c}0.036 \\
(0.015)\end{array}$ & $\begin{array}{c}0.029 \\
(0.016)\end{array}$ & $\begin{array}{c}0.040 \\
(0.023)\end{array}$ & $\begin{array}{c}0.040 \\
(0.023)\end{array}$ \\
\hline COMPETITION & $\begin{array}{c}0.863 \\
(0.319)\end{array}$ & $\begin{array}{c}0.729 \\
(0.322)\end{array}$ & $\begin{array}{c}0.852 \\
(0.465)\end{array}$ & $\begin{array}{c}0.852 \\
(0.465)\end{array}$ \\
\hline FREQUENCY & & $\begin{array}{c}0.120 \\
(0.083)\end{array}$ & $\begin{array}{c}0.165 \\
(0.123)\end{array}$ & \\
\hline ETHNIC & & & $\begin{array}{c}0.847 \\
(0.651)\end{array}$ & \\
\hline $\begin{array}{l}\text { LENGTH* } \\
\text { COMPETITION }\end{array}$ & & & & $\begin{array}{c}0.036 \\
(0.024)\end{array}$ \\
\hline Chi2 & 11.73 & 10.28 & 10.64 & 14.14 \\
\hline Log likelihood & -185.67 & -159.17 & -78.57 & -184.47 \\
\hline Obs. & 527 & 452 & 231 & 527 \\
\hline
\end{tabular}

Notes: Standard errors in parentheses. Please see Appendix for variable definitions. 